American Journal of Applied Sciences 7 (4): 459-465, 2010

ISSN 1546-9239

(C) 2010Science Publications

\title{
Effects of Cycocel and Irrigation Regimes on Some Physiological Parameters of Three Olive Cultivars
}

\author{
${ }^{1}$ Maisam Nejadsahebi, ${ }^{1}$ Noorollah Moallemi and ${ }^{2}$ Ahmad Landi \\ ${ }^{1}$ Department of Horticulture College of Agriculture, \\ ${ }^{2}$ Department of Soil Science College of Agriculture, \\ Shahid Chamran University, Ahvaz, Iran
}

\begin{abstract}
Problem statement: The water deficiency is one of the serious problems, in the arid zones. Cycocel by increasing the stomata resistance and decreasing transpiration can help to water use efficiency. Approach: In this research the impacts of different doses of Cycocel (0, 500 and $\left.1000 \mathrm{mg} \mathrm{L}^{-1}\right)$ and irrigation regimes (33, 66 and $100 \%$ of available water; referred to as $I_{1}, I_{2}$ and $I_{3}$, respectively) on some physiological parameters of three olive cultivars (Baghmalek, Fishami and Dezfuli) were investigated. The experiment design was factorial split in completely randomize. Measured parameters included fresh and dry weight of root and stem, root length, leaf area, Relative Water Content (RWC), stomata resistance and ratio of total fresh and dry weight of shoot to root. Results: Results showed that drought stress decreased stem fresh weight from $24 \mathrm{~g}$ for well Irrigated $\left(\mathrm{I}_{1}\right)$ compared to $17.5 \mathrm{~g}$ for drought stress treatment $\left(\mathrm{I}_{3}\right)$. Fishami cultivar indicated highest fresh and dry of stem (28.15 and $16.52 \mathrm{~g}$ ), leaf (12.97 and $9.44 \mathrm{~g}$ ) and root (25.34 and $7.99 \mathrm{~g}$ respectively) compared to other two cultivars. Olive plants in $\mathrm{I}_{3}$ treatments had higher stomata resistance $\left(46.05 \mathrm{sec} \mathrm{cm}^{-1}\right)$ and lower RWC (54.92\%). $\mathrm{C}_{3}$ treatment resulted in highest stomata resistance (28.18 and $42.81 \mathrm{sec} \mathrm{cm}{ }^{-1}$ measured in the morning and at noon, respectively); the corresponding values for $\mathrm{C}_{1}$ treatment were 22.26 and $28.93 \mathrm{sec} \mathrm{cm}^{-1}$. Conclusion: Results suggested that $\mathrm{I}_{2}$ and $\mathrm{cv}$. Fishami were superior compared to other irrigation treatments and cultivars. Cycocel adjusted drought neutralized negative effects of drought stress.
\end{abstract}

Key word: Olive, cycocel, irrigation treatment, stomata resistance, drought stress

\section{INTRODUCTION}

Drought stress is an environmental stressmaking factor confronting agricultural production. Drought stress reduces growth indexes of different plants (Chartzoulakis et al., 1999). One method to regulate and enhance water use efficiency is using tolerant plants to arid and semiarid environment. Olive (Olea europaea L.), an ever-green fruit tree, is a native plant in the semi-arid Mediterranean climate. In this type of climate the plants are subjecting to both heat and drought stress during summer (Gimenez et al., 1997; Saei et al., 2006). Native plants in this climate have usually developed some physiological tolerance mechanisms, resulting in better adaptation and surviving.

The adaptation mechanisms of olive are similar to other plants; include decreasing leaf water potential, osmotic adjustment, stomata closure, reduction of leaf size, leaf rolling, increasing mesophyll compactness and accumulation of mucilage and other secondary metabolites (Giorio et al., 1999; Bosabalidis and Kofidis, 2002). The role of olive roots in adaptation to dry conditions has been reported extensively (Fernandez et al., 1994; Rieger, 1995). Some researchers (Fernandez et al., 1994) noted that dense packing of the mesophyll layer in olive leaves of the commercial variety of Ascolana leads to a low cellular wall conductance thus providing an efficient system to limit cellular water loss under stress. Relative Water Content (RWC) is an appropriate measure of plant water status in regards to the physiological consequence of cellular water deficit. While water potential is a useful estimation of plant water status in dealing with water transport in the soil-plant-atmosphere continuum, it does not account for osmotic adjustment. The osmotic adjustment is a mechanism of conserving cellular hydration under drought stress and RWC expresses the effect of OA in this respect. Hence RWC is an appropriate estimate of plant water status in terms of

Corresponding Author: Noorollah Moallemi, Department of Horticulture College of Agriculture, Shahid Chamran University, Ahvaz, Iran Tel: +986113363054 Fax: +986113330079 
cellular hydration under the effect of both leaf water potential and osmotic adjustment (Gonzalez and Gonzalez-Vila, 2001).

Chemical products such as 2-chloroethyltrimethyl ammonium chloride (Cycocel; hereafter referred to as CCC)-is a synthetic plant growth retardant (antitranspiration)-have been previously found to increase the resistance of various plants to drought stress (Malash and Flower, 1984; Jaana et al., 2002). Limited available water resources in arid and semiarid zones, lack of regular and suitable distribution of rain in the growing season are justifying the research on the effects of stress related to irrigation rate on olive plant.

The objective of this research was to assess the effect off CCC on root system and aerial parts of olive plant under different irrigation treatments.

\section{MATERIALS AND METHODS}

The trial was carried out in 2006 at the experimental farm of Horticultural Department of Chamran University in southwestern of Iran $\left(31^{\circ} 20^{\prime} \mathrm{N}\right.$ and $48^{\circ} 40^{\prime} \mathrm{N}, 22 \mathrm{~m}$ above sea level). A mixture of a sandy clay loam soil, sand and decomposed manure at a 2:2:1 ratio was used. Each pot $(40 \mathrm{~cm}$ height and $30 \mathrm{~cm}$ diameter) contained $8 \mathrm{~kg}$ of soil, $8 \mathrm{~kg}$ of sand and $4 \mathrm{~kg}$ of manure. The sandy clay loam soil had $0.82 \% \mathrm{~N}$, $8 \mathrm{mg} \mathrm{kg}^{-1} \mathrm{P}, 194.84 \mathrm{mg} \mathrm{kg}^{-1} \mathrm{~K}, 1.9 \mathrm{EC}\left(\mathrm{dS} \mathrm{m}{ }^{-1}\right.$ ), pH of 7.6 and the volumetric soil water content at field capacity and permanent wilting point of 31 and $15 \%$, respectively. The data for annual precipitation and temperature were taken from the site nearby research station has shown in Table 1.

One year-old trees (Olean europe L.) of three cultivars of Baghmalek, Fishami and Dezfuli were transplanted in plastic pots in January 2006. Each pot was filled with $20 \mathrm{~kg}$ of soil mixture and15 g ammonium-phosphate was also added to each pots.

Three irrigation treatments including $33\left(\mathrm{I}_{1}\right), 66\left(\mathrm{I}_{2}\right)$ and $100 \%\left(I_{3}\right)$ of available water was used. The soil available water was $16 \%$ (31-15). Therefore, the irrigation of $I_{1}, I_{2}$ and $I_{3}$ was carried out when the corresponding soil water contents were 25.7, 20.4 and $15 \%$, respectively. During the study, the soil moisture was determined by $\mathrm{HH} 2$ portable hygrometer at depth of $15 \mathrm{~cm}$. Based on the measured soil moisture the irrigation treatments were implemented. Plastic cover was used to prevent the rainfall effect during the rainy days. Three months after implementing irrigation treatments plants were sprayed with 0,500 and $1000 \mathrm{mg} \mathrm{L}^{-1}$ CCC dissolved in water, hereafter referred to as $\mathrm{C}_{1}, \mathrm{C}_{2}$ and $\mathrm{C}_{3}$, respectively. This experiment was included 27 treatments ( 3 olive cultivars, 3 doses of cycocel and 3 irrigation regimes) and 4 replications. The experiment design was factorial split in completely randomize.

Measured parameters included: Fresh and dry weight of root, stem and leaf, area of leaf and root, root length, Relative Water Content (RWC) and stomata resistance. The youngest leaves of each treatment were used to measure RWC. Top-most fully expanded leaves are sampled and leaf discs were cut from the leaves, In the Lab vials were weighed to obtain leaf Weight (FW), after which the sample was immediately hydrated in a close Petri dish to full turgidity for $5 \mathrm{~h}$. After $5 \mathrm{~h}$ the samples were taken out of water and well dried of any surface moisture with filter paper and immediately weighed to obtain fully turgid Weight (SW). The Dry Weight (DW) of samples was obtained after drying at $70^{\circ} \mathrm{C}$ for $48 \mathrm{~h}$. The RWC is estimated as follow:

$$
\text { RWC }(\%)=[(F W-D W) /(S W-D W)] \times 100
$$

Stomata resistance was measured by using Porometer AP4 Delta-T Devices Cambridge-UK once a week for 4 consecutive weeks after cycocel was sprayed; the measurement in each day was carried out at 5:00 am and 12:00 pm. In each stage, 3 leaves of each plant were selected and the parameters were measured at end of experiment.

Olive plants were removed from soil, washed off any soil and removed surface moisture. The plants were separated into leaves, stems and roots. And the fresh weight of each was separately determined. Leaf area was measured using the Area Meter MK2 device (Delta-T Device). Root length and area were measured after immersing in Methyl Blue solution for $10 \mathrm{~min}$. Root length and area were then determined using root scanner. The root, stem and leaves were separately oven dried at $70^{\circ} \mathrm{C}$ for $48 \mathrm{~h}$ and the dry weights were measured. The root/shoot ratio was then calculated for each treatment.

Data were statistically analyzed using analysis of variance and mean comparisons using Duncan's Multiple Rang Test (DMRT) (Gomez and Gomez, 1984).

Table 1: Climatic condition during the experiment

\begin{tabular}{lccc}
\hline & & Monthly temperature $\left({ }^{\circ} \mathrm{C}\right)$ \\
Month & Rainfall $(\mathrm{mm})$ & Min. & Max. \\
\hline Dec.-Jan. & 48.2 & 7.00 & 17.4 \\
Jan.-Feb. & 27.0 & 8.50 & 20.2 \\
Feb.-March & 29.5 & 12.1 & 25.1 \\
March-April & 15.1 & 17.2 & 32.1 \\
April-May & 5.2 & 22.5 & 39.0 \\
May-June & - & 25.5 & 44.4 \\
June-July & - & 27.7 & 46.2 \\
\hline
\end{tabular}




\section{RESULTS}

Irrigation treatments: The interactive effects of all measured parameters were significant at $1 \%$ level (Table 2). The dry weight of root, stem and leaf reduced with increasing of drought stress.

In this research, we found that the fresh and dry weight (stem, leaf and root) and leaf area reduced significantly $(\mathrm{p}<0.01)$ by reduction of irrigation water rate (Table 3 ). The differences between cultivars, in respect of fresh and dry weights (stem, leaf, root) and leaf area were significant $(\mathrm{p}<0.01)$.

Drought stress decreased stem fresh weight from $24 \mathrm{~g}$ for well irrigated treatment compared to $17.5 \mathrm{~g}$ for severe drought stress treatment. The dry weights of both stem and leaves were decreased substantially by increasing drought stress. Leaf area decreased from $0.039-0.025 \mathrm{~m}^{2}$ by decreasing the available water. Drought stress also decreased the area and length of roots. Root length decreased from $31.79 \mathrm{~m}$ for $\mathrm{I}_{1}$ to $29.30 \mathrm{~m}$ for $\mathrm{I}_{3}$ treatment.
Table 4 shows changes in olive characteristics for different cultivars. Fishami cultivar indicated the highest dry and fresh weight of stem, leaf and root compared to other two cultivars. Stem fresh weight for Fishami, Baghmalek and Dezfuli cultivars were 28.15, 18.96 and 16.03 g, respectively. Also, Fishami cultivar indicated higher root area and length, stomata resistance and relative water content compared to other two cultivars (Table 4). The order of fresh and dry weights (stem, leaf and root) and leaf area of different cultivars are as follow:

\section{Fishami $>$ Dezfuli $>$ Baghmalek}

Root area was reduced by shortage of available water. However, root length was initially increased by reduction of available water, $\mathrm{I}$, e., from $\mathrm{I}_{1}$ and further water shortage (from $I_{2}$ to $I_{3}$ ) resulted in lower root length $\left(I_{3}\right)$. The ratio of both total fresh dry weight of shoot to root reduced by increasing drought stress (Table 3).

Table 2: Mean squire of measured parameters of stem, leaf, root, total weight and stomata resistance of interactive effects of irrigation treatments and Cycocel application for different olive cultivars

\begin{tabular}{|c|c|c|c|c|c|c|c|c|c|c|c|c|c|c|c|}
\hline \multirow[b]{2}{*}{$\begin{array}{l}\text { Source of } \\
\text { variation }\end{array}$} & \multirow[b]{2}{*}{ df } & \multicolumn{2}{|l|}{ Stem } & \multicolumn{3}{|l|}{ Leaf } & \multicolumn{4}{|l|}{ Root } & \multicolumn{2}{|c|}{ Total shoot root } & \multicolumn{2}{|c|}{ Stomata resistance } & \multirow[b]{2}{*}{$\begin{array}{l}\text { RWC } \\
(\%)\end{array}$} \\
\hline & & $\begin{array}{l}\text { Fresh } \\
\text { weight } \\
\text { (g) }\end{array}$ & $\begin{array}{l}\text { Dry } \\
\text { weight } \\
\text { (g) }\end{array}$ & $\begin{array}{l}\text { Fresh } \\
\text { weight } \\
\text { (g) }\end{array}$ & $\begin{array}{l}\text { Dry } \\
\text { weigh } \\
\text { (g) }\end{array}$ & $\begin{array}{l}\text { Area } \\
\left(\mathrm{m}^{2}\right)\end{array}$ & $\begin{array}{l}\text { Fresh } \\
\text { weigh } \\
\text { (g) }\end{array}$ & $\begin{array}{l}\text { Dry } \\
\text { weigh } \\
\text { (g) }\end{array}$ & $\begin{array}{r}\text { Area } \\
\left(\mathrm{m}^{2}\right)\end{array}$ & $\begin{array}{l}\text { Length } \\
\text { (m) }\end{array}$ & $\begin{array}{l}\text { Dry } \\
\text { weight } \\
\text { (g) }\end{array}$ & $\begin{array}{l}\text { Fresh } \\
\text { weight } \\
\text { (g) }\end{array}$ & $\begin{array}{l}5 \mathrm{am} \\
\left(\mathrm{sec} \mathrm{cm}^{-1}\right)\end{array}$ & $\begin{array}{l}12 \mathrm{pm} \\
\left(\mathrm{sec} \mathrm{cm} \mathrm{cm}^{-1}\right)\end{array}$ & \\
\hline$\overline{\text { Cultivar (Cu) }}$ & 2 & $1438.10^{* *}$ & $465.5^{* *}$ & $35.60 * *$ & $27.30 * *$ & $53.7 * *$ & $1630.1^{* *}$ & $119.3^{* *}$ & $419.3^{* *}$ & $3472143.6^{* *}$ & $4.1^{* *}$ & $3.4^{* *}$ & $3926.0 * *$ & $857.0^{* *}$ & $114.7^{* *}$ \\
\hline CCC (Cc) & 2 & $52.50^{* *}$ & $13.4^{* *}$ & $6.50 * *$ & $4.80 * *$ & $89.3 * *$ & $6.2^{* *}$ & $12.8 * *$ & $0.7^{* *}$ & $64501.7 * *$ & $10.1^{* *}$ & $0.17^{* *}$ & $1739.0 * *$ & $1012.0^{* *}$ & $89.6 * *$ \\
\hline $\mathrm{Cu} \times \mathrm{Cc}$ & 4 & $102.30 * *$ & $26.2 * *$ & $30.80^{* *}$ & $2.60 * *$ & $140.3^{* *}$ & $55.2 * *$ & $20.6 * *$ & $51.2 * *$ & $806381.6 * *$ & $39.1^{* *}$ & $0.11 * *$ & $334.0 * *$ & $280.0 * *$ & $109.0^{* *}$ \\
\hline Irri. (I) & 2 & $432.70^{* *}$ & $74.6 * *$ & $47.70^{* *}$ & $95.10^{* *}$ & $1768.9 * *$ & $435.6^{* *}$ & $12.0 * *$ & $23.8^{* *}$ & $160888.4^{* *}$ & $9.7^{* *}$ & $0.5^{* *}$ & $3076.0 * *$ & $2796.0^{* *}$ & $7.2^{* *}$ \\
\hline $\mathrm{Cu} \times \mathrm{I}$ & 4 & $52.10^{* *}$ & $17.2^{* *}$ & $9.00 * *$ & $4.70^{* *}$ & $101.1^{* *}$ & $59.4^{* *}$ & $7.6^{* *}$ & $6.9^{* *}$ & $53019.4^{* *}$ & $3.6^{* *}$ & $0.1^{* *}$ & $1006.0 * *$ & $967.0 * *$ & $97.6^{* *}$ \\
\hline $\mathrm{Cc} \times \mathrm{I}$ & 4 & $341.64 *$ & $33.9^{* *}$ & $23.25 * *$ & $15.80 * *$ & $189.7^{* *}$ & $38.6^{* *}$ & $7.2 * *$ & $8.4^{* *}$ & $222854.9^{* *}$ & $20.7 * *$ & $0.4^{* *}$ & $1364.0^{* *}$ & $376.0 * *$ & $23.7^{* *}$ \\
\hline $\mathrm{Cc} \times \mathrm{Cu} \times \mathrm{I}$ & 8 & $91.90^{* *}$ & $256.3^{*}$ & $29.70 * *$ & $12.45 * *$ & $104.6^{* *}$ & $102.0^{* *}$ & $13.1^{* *}$ & $42.4^{* *}$ & $329042.7 * *$ & $39.2 * *$ & $0.6^{* *}$ & $987.0 * *$ & $256.0 * *$ & $425.4 * *$ \\
\hline CV (\%) & & 7.50 & 14.1 & 9.30 & 12.40 & 22.2 & 13.1 & 1.7 & 18.9 & 21.4 & 6.2 & 21.2 & 14.9 & 17.4 & 17.2 \\
\hline
\end{tabular}

* and **: Significant at $\mathrm{p}<0.05$ and $\mathrm{p}<0.01$ levels, respectively; CV: Coefficient of Variation

Table 3: Influence of irrigation treatments on some growth parameters olive plants

\begin{tabular}{|c|c|c|c|c|c|c|c|c|c|c|c|c|c|c|}
\hline \multirow[b]{3}{*}{$\begin{array}{l}\text { Irrigation } \\
\text { treatment }\end{array}$} & \multicolumn{2}{|l|}{ Stem } & \multicolumn{3}{|l|}{ Leaf } & \multicolumn{4}{|l|}{ Root } & \multicolumn{2}{|c|}{ Total shoot root } & \multirow{2}{*}{\multicolumn{2}{|c|}{ Stomata resistance }} & \multirow[b]{3}{*}{$\begin{array}{l}\text { RWC } \\
(\%)\end{array}$} \\
\hline & Fresh & Dry & Fresh & Drv & & Fres & Drv & & & Drv & Fresh & & & \\
\hline & $\begin{array}{l}\text { weight } \\
\text { (g) }\end{array}$ & $\begin{array}{l}\text { weight } \\
\text { (g) }\end{array}$ & $\begin{array}{l}\text { weight } \\
\text { (g) }\end{array}$ & $\begin{array}{l}\text { weigh } \\
\text { (g) }\end{array}$ & $\begin{array}{l}\text { Area } \\
\left(\mathrm{m}^{2}\right)\end{array}$ & $\begin{array}{l}\text { weigh } \\
\text { (g) }\end{array}$ & $\begin{array}{l}\text { weigh } \\
\text { (g) }\end{array}$ & $\begin{array}{l}\text { Area } \\
\left(\mathrm{m}^{2}\right)\end{array}$ & $\begin{array}{l}\text { Length } \\
\text { (m) }\end{array}$ & $\begin{array}{l}\text { weight } \\
\text { (g) }\end{array}$ & $\begin{array}{l}\text { weight } \\
\text { (g) }\end{array}$ & $\begin{array}{l}5 \mathrm{am} \\
\left(\mathrm{sec} \mathrm{cm}^{-1}\right)\end{array}$ & $\begin{array}{l}12 \mathrm{pm} \\
\left(\mathrm{sec} \mathrm{cm}^{-1}\right)\end{array}$ & \\
\hline$\overline{\mathrm{I}_{1}}$ & $24.42^{\mathrm{a}}$ & $13.91^{\mathrm{a}}$ & $15.07^{\mathrm{a}}$ & $10.29^{\mathrm{a}}$ & $0.039^{\mathrm{a}}$ & $20.77^{\mathrm{a}}$ & $6.60^{\mathrm{a}}$ & $0.0134^{\mathrm{a}}$ & $31.79^{b}$ & $2.04^{\mathrm{a}}$ & $4.12^{\mathrm{a}}$ & $15.34^{\mathrm{c}}$ & $28.30^{c}$ & $55.81^{\mathrm{a}}$ \\
\hline $\mathrm{I}_{2}$ & $21.22^{\mathrm{b}}$ & $12.63^{b}$ & $11.61^{\mathrm{b}}$ & $8.83^{b}$ & $0.032^{\mathrm{b}}$ & $19.08^{b}$ & $6.06^{\mathrm{b}}$ & $0.0131^{\mathrm{b}}$ & $33.50^{\mathrm{a}}$ & $1.95^{\mathrm{b}}$ & $3.86^{\mathrm{b}}$ & $20.24^{\mathrm{b}}$ & $32.67^{b}$ & $55.44^{\mathrm{b}}$ \\
\hline $\mathrm{I}_{3}$ & $17.49^{\mathrm{C}}$ & $11.04^{\mathrm{c}}$ & $8.86^{\mathrm{c}}$ & $7.04^{c}$ & $0.025^{c}$ & $14.08^{\mathrm{c}}$ & $5.44^{\mathrm{C}}$ & $0.0119^{c}$ & $29.30^{c}$ & $1.92^{\mathrm{c}}$ & $3.39^{c}$ & $32.46^{\mathrm{a}}$ & $46.05^{\mathrm{a}}$ & $54.92^{c}$ \\
\hline
\end{tabular}

Table 4: Influence of cultivar on some growth parameters olive plants

\begin{tabular}{|c|c|c|c|c|c|c|c|c|c|c|c|c|c|c|}
\hline \multirow[b]{3}{*}{ Cultivar } & \multicolumn{2}{|c|}{ Stem weight } & \multicolumn{3}{|l|}{ Leaf } & \multicolumn{4}{|l|}{ Root } & \multicolumn{2}{|c|}{ Total shoot root } & \multirow{2}{*}{\multicolumn{2}{|c|}{ Stomata resistance }} & \multirow[b]{3}{*}{$\begin{array}{l}\text { RWC } \\
(\%)\end{array}$} \\
\hline & Fresh & Dry & Fresh & Dry & & Fresh & Dry & & & Dry & Fresh & & & \\
\hline & $\begin{array}{l}\text { Weight } \\
\text { (g) }\end{array}$ & $\begin{array}{l}\text { weight } \\
\text { (g) }\end{array}$ & $\begin{array}{l}\text { weight } \\
\text { (g) }\end{array}$ & $\begin{array}{l}\text { weigh } \\
\text { (g) }\end{array}$ & $\begin{array}{l}\text { Area } \\
\left(\mathrm{m}^{2}\right)\end{array}$ & $\begin{array}{l}\text { weigh } \\
\text { (g) }\end{array}$ & $\begin{array}{l}\text { weigh } \\
\text { (g) }\end{array}$ & $\begin{array}{l}\text { Area } \\
\left(\mathrm{m}^{2}\right)\end{array}$ & $\begin{array}{l}\text { Length } \\
\text { (m) }\end{array}$ & $\begin{array}{l}\text { weight } \\
\text { (g) }\end{array}$ & $\begin{array}{l}\text { weight } \\
\text { (g) }\end{array}$ & $\begin{array}{l}5 \mathrm{am} \\
\left(\mathrm{sec} \mathrm{cm}^{-1}\right)\end{array}$ & $\begin{array}{l}2 \mathrm{pm} \\
\left(\mathrm{sec} \mathrm{cm}^{-1}\right)\end{array}$ & \\
\hline Baghmalek & $16.03^{\mathrm{c}}$ & $9.55^{c}$ & $11.08^{\mathrm{c}}$ & $7.75^{\mathrm{c}}$ & $0.032^{\mathrm{b}}$ & $12.15^{\mathrm{c}}$ & $4.40^{\mathrm{C}}$ & $0.019^{\mathrm{c}}$ & $23.56^{\mathrm{c}}$ & $2.27^{\mathrm{a}}$ & $4.05^{\mathrm{a}}$ & $17.7^{\mathrm{c}}$ & $32.8^{\mathrm{b}}$ & $53.54^{\mathrm{c}}$ \\
\hline Fishami & $28.15^{\mathrm{a}}$ & $16.52^{\mathrm{a}}$ & $12.97^{\mathrm{a}}$ & $9.44^{\mathrm{a}}$ & $0.033^{\mathrm{a}}$ & $25.34^{\mathrm{a}}$ & $7.99^{\mathrm{a}}$ & $0.017^{\mathrm{a}}$ & $42.50^{\mathrm{a}}$ & $1.67^{\mathrm{c}}$ & $3.58^{\mathrm{c}}$ & $27.5^{\mathrm{a}}$ & $47.2^{\mathrm{a}}$ & $57.10^{\mathrm{a}}$ \\
\hline Dezfuli & $18.96^{\mathrm{b}}$ & $11.51^{\mathrm{b}}$ & $11.49^{b}$ & $8.97^{b}$ & $0.032^{\mathrm{C}}$ & $16.44^{\mathrm{b}}$ & $5.71^{\mathrm{b}}$ & $0.012^{\mathrm{b}}$ & $28.53^{b}$ & $1.84^{\mathrm{b}}$ & $3.76^{\mathrm{b}}$ & $22.8^{\mathrm{b}}$ & $26.9^{c}$ & $55.53^{b}$ \\
\hline
\end{tabular}

${ }^{\mathrm{a}-\mathrm{c}}$ : Significant at $1 \%$ level 
Am. J. Applied Sci., 7 (4): 459-465, 2010

Table 5: Effect of cycocel on some growth parameters olive plants

\begin{tabular}{|c|c|c|c|c|c|c|c|c|c|c|c|c|c|c|}
\hline \multirow{3}{*}{$\begin{array}{l}\text { Cycocel } \\
\text { doses } \\
\left(\mathrm{mg} \mathrm{L}^{-1}\right)\end{array}$} & \multicolumn{2}{|l|}{ Stem } & \multicolumn{3}{|l|}{ Leaf } & \multicolumn{4}{|l|}{ Root } & \multicolumn{2}{|c|}{ Total shoot root } & \multirow{2}{*}{\multicolumn{2}{|c|}{ Stomata resistance }} & \multirow[b]{3}{*}{$\begin{array}{l}\text { RWC } \\
\text { (\%) }\end{array}$} \\
\hline & \multirow{2}{*}{$\begin{array}{l}\text { Fresh } \\
\text { Weight } \\
\text { (g) }\end{array}$} & \multirow{2}{*}{$\begin{array}{l}\text { Dry } \\
\text { weight } \\
\text { (g) }\end{array}$} & \multirow{2}{*}{$\begin{array}{l}\text { Fresh } \\
\text { weight } \\
\text { (g) }\end{array}$} & \multirow{2}{*}{$\begin{array}{l}\text { Dry } \\
\text { weigh } \\
\text { (g) }\end{array}$} & \multirow[b]{2}{*}{$\begin{array}{l}\text { Area } \\
\left(\mathrm{m}^{2}\right)\end{array}$} & \multirow{2}{*}{$\begin{array}{l}\text { Fresh } \\
\text { weigh } \\
\text { (g) }\end{array}$} & \multirow{2}{*}{$\begin{array}{l}\text { Dry } \\
\text { weigh } \\
\text { (g) }\end{array}$} & \multirow[b]{2}{*}{$\begin{array}{l}\text { Area } \\
\left(\mathrm{m}^{2}\right)\end{array}$} & \multirow[b]{2}{*}{$\begin{array}{l}\text { Length } \\
\text { (m) }\end{array}$} & \multirow{2}{*}{$\begin{array}{l}\text { Dry } \\
\text { weight } \\
\text { (g) }\end{array}$} & \multirow{2}{*}{$\begin{array}{l}\text { Fresh } \\
\text { weight } \\
\text { (g) }\end{array}$} & & & \\
\hline & & & & & & & & & & & & $\begin{array}{l}5 \mathrm{am} \\
\left(\mathrm{sec} \mathrm{cm}^{-1}\right)\end{array}$ & $\begin{array}{l}12 \mathrm{pm} \\
\left(\mathrm{sec} \mathrm{cm}^{-1}\right)\end{array}$ & \\
\hline 0 & $19.97^{c}$ & $13.20^{\mathrm{a}}$ & $11.44^{\mathrm{C}}$ & $8.97^{\mathrm{a}}$ & $0.033^{\mathrm{a}}$ & $17.58^{\mathrm{C}}$ & $5.36^{c}$ & $0.0127^{\mathrm{b}}$ & $33.05^{\mathrm{a}}$ & $1.87^{\mathrm{C}}$ & $\frac{1}{42^{\mathrm{a}}}$ & $22.26^{\mathrm{c}}$ & $28.93^{\mathrm{C}}$ & $54.36^{c}$ \\
\hline 500 & $23.35^{\mathrm{a}}$ & 12.3 & $12.29^{\mathrm{a}}$ & $8.89^{\mathrm{b}}$ & $0.032^{\mathrm{b}}$ & $18.41^{\mathrm{a}}$ & $6.47^{\mathrm{a}}$ & $0.0128^{\mathrm{b}}$ & $31.01^{\mathrm{b}}$ & $2.00^{\mathrm{a}}$ & $3.54^{\mathrm{b}}$ & $23.00^{\mathrm{b}}$ & $35.29^{\mathrm{b}}$ & $57.20^{\mathrm{a}}$ \\
\hline 1000 & $20.82^{\mathrm{b}}$ & $12.36^{\mathrm{b}}$ & $11.80^{\mathrm{b}}$ & $8.30^{\mathrm{c}}$ & $0.030^{\mathrm{c}}$ & $17.95^{\mathrm{b}}$ & $6.26^{\mathrm{b}}$ & $0.0130^{\mathrm{a}}$ & $30.53^{c}$ & $1.91^{\mathrm{b}}$ & $3.16^{\mathrm{c}}$ & $28.18^{\mathrm{a}}$ & $42.81^{\mathrm{a}}$ & $54.60^{\mathrm{b}}$ \\
\hline
\end{tabular}

Different letters indicate significant differences at $1 \%$ level

Results indicated that the reduction of irrigation level reduced the Relative Water Content (RWC) (Table 3). Fishami cultivar showed the highest RWC compared to other cultivars (Table 4). The RWC is influenced by plant genetic. It seems that Fishami cultivar endures drought more than the others by keeping leaf water potential low in drought stress and hence can absorb more water in drought stress compared to other cultivars

Cycocel treatments: Application of Cycocel up to $500 \mathrm{mg} \mathrm{L}^{-1}\left(\mathrm{C}_{2}\right)$ improved plant performance; further application (e.g., $1000 \mathrm{mg} \mathrm{L}^{-1}$ ) reduced the plant performance. Stem fresh weight was highest (22.35 g) for $500 \mathrm{mg} \mathrm{L}^{-1}$ Cycocel compared to 20.82 and $19.97 \mathrm{~g}$ for $1000\left(C_{3}\right)$ and $0\left(C_{1}\right) \mathrm{mg} \mathrm{L}^{-1}$ application of Cycocel. Similarly, leaf and root fresh weights were highest for $\mathrm{C}_{2}$ treatment. However, $\mathrm{C}_{3}$ treatment resulted in highest stomata resistance (28.18 and $42.81 \mathrm{sec} \mathrm{cm}^{-1}$ measured in the morning and at noon, respectively); the corresponding values for $\mathrm{C}_{1}$ treatment were 22.26 and $28.93 \mathrm{sec} \mathrm{cm}^{-1}$.

The dry weights of shoot and leaf area reduced while fresh weight organs increased significantly by increasing Cycocel doses (Table 5). Dry weight of roots increased significantly by using Cycocel (Table 5). The ratio of total fresh weight of shoot to root increased significantly by increasing Cycocel application. However, application of Cycocel reduced the ratio of dry weight of shoot to root (Table 5).

The interactive effects of all treatments on olive root system revealed that the application of 0 and $500 \mathrm{mg} \mathrm{L}^{-1}$ doses of Cycocel and all irrigation treatments of all cultivars resulted in an increase in root area and the reduction of root length (Fig. 1).

Our results indicated that RWC increased significantly by using Cycocel (Table 5). Stomata resistance changed from $22.26 \mathrm{sec} \mathrm{cm}^{-1}$ in the morning to $28.93 \mathrm{sec} \mathrm{cm} \mathrm{cm}^{-1}$ at noon for control plant. Application of $500 \mathrm{mg} \mathrm{L}^{-1}$ Cycocel resulted in increasing stomata resistance to 23 at 5 am and $35.29 \mathrm{sec} \mathrm{cm}{ }^{-1}$ at $12 \mathrm{pm}$. Further increase in stomata resistance to 28.18 (measured at $5 \mathrm{am}$ ) and $43.81 \mathrm{sec} \mathrm{cm} \mathrm{cm}^{-1}$ (measured at $12 \mathrm{pm}$ ) was recorded when olives treated with $1000 \mathrm{mg} \mathrm{L}^{-1}$ of Cycocel (Table 5).

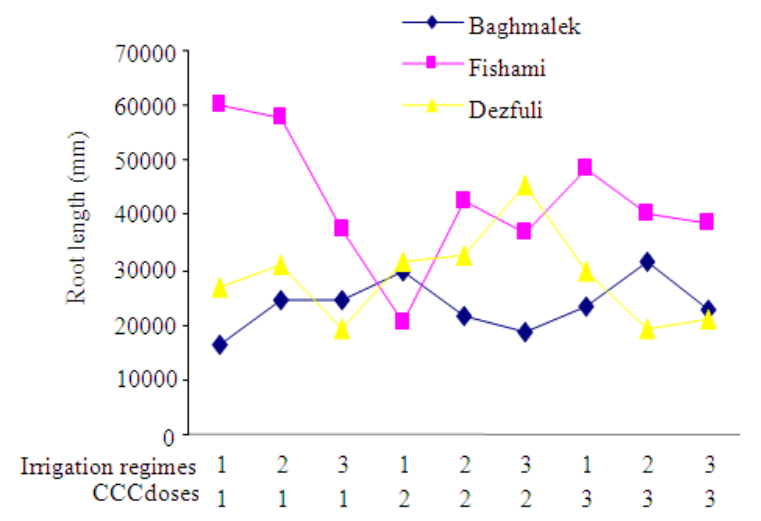

(A)

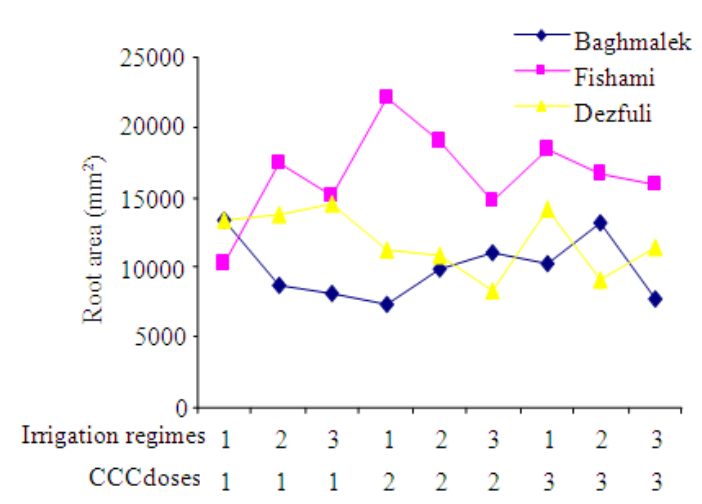

(B)

Fig. 1: Interactive effects of cultivars, Cycocel doses and irrigation regimes on root length (A) root area and (B)

\section{DISCUSSION}

In this experiment we found that fresh and dry weight (stem, leaf, and root) and leaf area reduced by reduction of irrigation water rate. Reduction in dry weight of root may be attributed to reducing the accumulation of root carbohydrates (Jaana et al., 2002). The water stress reduces translocation of organic compounds and possibly changes the way of transferring materials. The reduction of produced 
materials that transfer to leaves is one of the factors which reduce the photosynthesis and hence declining the dry weight organs and growth of plants. The first symptom of water shortage is usually limitation of leaf growth. In drought stress conditions, the leaf growth is less sensitive than the creation of new leaves (Ismail et al., 2004). Results presented in this study are similar to those reported by Saei et al. (2006). They reported that plants subjected to water stress, not only have lower growth rate but also their structural characteristics, specially their leaves changed. Other crops such as tomatoes had fewer leaf area and fewer succulent shoots comparing with control plants under drought stress (Torrecillas et al., 1995).

Fernandez et al. (1994) found that rainfed olive roots were more concentrated around stem with longer distances than the irrigated olive roots. Root growth rate directly related to soil water content (Fernandez et al., 1994; Dichio et al., 2002; Sofo et al., 2004). Under stress conditions, the shoots lose more water than roots (Torrecillas et al., 1995). Many plant spices tolerate to water stress by increasing assimilation which is allotted to root growth. This may be due to different range of sensitivities to internal Abcisic Acid (ABA) by root and shoot and also osmosis regulation in roots (Dichio et al., 2002; Sofo et al., 2004). Kramer and Kozlowski (1979) and Xudan (1986) reported that roots are the strongest antagonists for obtaining accessible assimilation materials particularly in drought resistant wheat cultivars.

Olive cultivars response to drought stress conditions using different mechanisms. Some cultivars employ either prodigal or conservative water-use-efficiency to better acclimate to drought stress (Bacelar et al., 2009). The results of this study are similar to others (Fernandez et al., 1994; Giorio et al., 1999). Similar trends were also reported for other plants such as banana (Ismail et al., 2004), tomato (Mishra and Pradhan, 1972; Malash and Flowers, 1984), rice and eggplant (Prakash and Ramachandran, 2000; Halder and Burrage, 2003).

Mishra and Pradhan (1972) and Malash and Flowers (1984) reported a decline of the dry weight of treated seeding of tomatoes following Cycocel application. Cycocel, by further closing of stomata and reducing of diffusion of carbon dioxide into leaf cells, causes reduction of both photosynthesis and total dry weight. On the other hands, Cycocel causes reduction of growth by preventing Gibberellic Acid (GA3) syntheses, which in turn reduces plant dry weight (Skene and Mullins, 1967; Jaana et al., 2002). Different factors can increase dry weight of roots in this condition: (A) Cycocel decreases shoot growth and more hydro carbonic and assimilation materials are accessible to roots. It also reduces the dose of carbon dioxide in leaf cells and photosynthesis (Skene and Mullins, 1967). (B) Interfacing stress conditions and stomata closure by Cycocel, dry weight of roots can be increased by osmosis regulation and increasing of soluble potassium and carbohydrates (Skene and Mullins, 1967). (C) Cycocel application rate increased the root area and this in turn resulted in increasing dry weight of root (Skene and Mullins, 1967). Jaana et al. (2002) reported that Cycocel increased dry and fresh weights of roots. Our results indicated that increasing doses of Cycocel decreased the root length while the root area increased. This shows that the application of Cycocel caused olives roots to become thicker and shorter. Skene and Mullins (1967) found roots of Vitis vinifera L. plants grown in solution cultures containing Cycocel were shorter and thicker than those of untreated control plants. Mishra and Pradhan (1972) and Malash and Flowers (1984) reported that Cycocel reduced shoot growth and hence the overall dry weight of plant and reducing the ratio of dry weight of shoot to root.

Skene and Mullins (1967) found that the CCC had markedly affected on the appearance of the roots. Associated with a decree in root length, root diameter was much greater than that of the untreated controls. This probably is a mechanism of olive adaptation, so that it compensates reducing root area in drought stress conditions by increasing its length. It also compensate reducing root length in presence of Cycocel, by increasing root area until the product of (root area $x$ root length) does not reduce from its minimum rate so that the plants be able to tolerate stress.

Prakash and Ramachandran (2000) reported that Cycocel application increased RWC of olive leaves. It is likely that the Cycocel application can affect the internal metabolisms of stomata cells. The more closing of stomata, recovers the efficiency of plant water usage until plant reduces transpiration, without any negative effects on stress tolerance (Mishra and Pradhan, 1972; Malash and Flowers, 1984; Giorio et al., 1999). Duration of stability of effect of Cycocel on stomata in this research was clear until the end of 4 weeks, so that until the end of experiment, stomata conductive of plants treated by Cycocel remained on a lower level compared to control plants. As leaves are the most important organs, which lose water, plants under drought stress undergo some changes in their leaves in order to save water (Chartzoulakis et al., 1999). The main change is the stomata closure in order to reduce transpiration rate and prevent water loss (Saei et al., 2006). Cycocel induced stomata closure and delayed wilting and the effect 
stabled about one week (Mishra and Pradhan, 1972; Malash and Flowers, 1984). Skene and Mullins (1967) showed that Cycocel reduced the number of stomata in dry farming-corn and in contrast the percentage of closed stomata increased. The results of this research are similar to other studies reported in the field of stomata resistant in response to shortage of water in rice (Halder and Burrage, 2003). Investigating the daily stomata behavior of potted olive leaves exposed to natural environmental conditions revealed that stomata opened early in the morning. However, by noon the rate of stomata opening decreased and almost remained steady all afternoon (Angelopoulos et al., 1996). In this research, stomata resistant was increased by reduction of irrigation level and increasing doses of Cycocel application, as a result of keeping RWC and reduction of transpiration. Similar results were reported by Malash and Flowers (1984); Skene and Mullins (1967); Dry et al. (1996) and Basinger and Hellman (2006).

In this research the increase in stomata resistance and reduction of stomata conductivity were observed. This result was also reported by Giorio et al. (1999) and Saei et al. (2006). Closing of stomata, as a result of drought stress, has been attributed to increasing of the distribution of Abcisic Acid from root to leaves (Levy et al., 1978; Abrisqueta et al., 2008). Stomata closure in plants is an adaptation mechanism to water deficit, which causes water saving and protect plants against drought stress (Moriana et al., 2002).

\section{CONCLUSION}

Drought stress reduced the olive performance. Among the three olive cultivars investigated, Fishami cultivar had more resistance to drought compare to Baghmalek and Dezfuli cultivars. Results showed that increasing doses of Cycocel in drought stress, increased biomass weight, RWC and stomata resistance. Cycocel adjusted and neutralized negative effects of drought stress.

\section{REFERENCES}

Abrisqueta, J.M., O. Mounzer, S. Alvarez, W. Conejero and Y. Garcia-Orellana et al., 2008. Root dynamics of peach trees submitted to partial rootzone drying and continuous deficit irrigation. Agric. Water Manage., 95: 959-967. $\quad$ DOI: 10.1016/j.agwat.2008.03.003.

Angelopoulos, K., B. Dichio and C. Xiloyannis, 1996. Inhibition of photosynthesis in olive trees (Olea europaea L.) during water stress and rewatering. J. Exp. Bot., 47: 1093-1100. DOI: 10.1093/jxb/47.8.1093
Basinger, A.B. and E.W. Hellman, 2006. Evaluation of regulated deficit irrigation on Grape in Texas and implications for acclimation and cold hardiness. Int. J. Fruit Sci., 6: 3-22. DOI: 10.1300/J492v06n02_02

Bacelar, E.A., J.M. Moutinho-Pereira, B.C. Gonçalves, J.I. Lopes and C.M. Correia, 2009. Physiological responses of different olive genotypes to drought conditions. Acta Physiol. Plantarum, 31: 611-621. DOI: 10.1007/511738-009-02772-9

Bosabalidis, A.M. and G. Kofidis, 2002. Comparative effects of drought on leaf anatomy of two olive cultivars. Pak. J. Bio. Sci., 163: 375-379. DOI: 10.1016/S0168-9452(02)00135-8

Chartzoulakis, K., A. Patakas and A.M. Bosabalidis, 1999. Changes in water relations, photosynthesis and leaf anatomy induced by intermittent drought in two olive cultivars. Environ. Exp. Bot., 42: 113120. DOI: 10.1016/S0098-8472(99)00024-6

Dichio, B., M.N. Romano and C. Xiloyannis, 2002. Soil water availability and relationship between canopy and roots in young olive trees (cv. Corotina). Acta Hort., 586: 255-257.

Dry, P., B. Loveys, D. Botting and H. During, 1996. Effect of partial root-zone drying on grapevine vigor, yield composition of fruit and use of water. Proceeding of the 9th Australian Wine Industry Technical Conference, Adelaide, SA., July 16-19, pp: 128-131.

Fernandez, J.E., M. Moreno, M.J., Martin-Aranda and H. F. Rapport, 1994. Anatomical response of olive roots to clay and irrigated soils. Adv. Hort. Sci., 8: 141-144. DOI: 10.1400/14307

Gimenez, C., E. Fereres, C. Ruz and F. Orgaz, 1997. Water relations and gas exchange of olive trees: Diurnal and seasonal patterns of leaf water potential, photosynthesis and stomata conductance. Acta Hort., 449: 411-416.

Giorio, P., G. Sorrentino and R. D'andria, 1999. Stomata behavior, leaf water status and photosynthetic response in field-grown olive trees under water deficit. Environ. Exp. Bot., 42: 95-104. DOI: 10.1016/S0098-8472(99)00023-4

Gomez, K.A. and A.A. Gomez, 1984. Statistical Procedures for Agricultural Research. 2nd Edn., John Wiley and Sons, Inc., New York, pp: 704.

Gonzalez, L. and M. Gonzalez-Vila, 2001. Determination of Relative Water Content. In: Handbook of Plant Ecophysiology Techniques, Roger, M.J.R. (Ed.). Springer, Netherlands, ISBN: 13: 978-0792370536, pp: 207-212.

Halder, K.P. and S.W. Burrage, 2003. Drought stress effects on water relations of rice grown in nutrient film technique. Pak. J. Biol. Sci., 6: 441-444. DOI: 10.3923/pjbs.2003.441.444 
Ismail, M.R., K. Yusoff and M. Mahmood, 2004. Growth, water relations, stomata conductance and proline concentration in water stressed banana (Musa spp.) plants. Asian J. Plant Sci., 3: 709713. DOI: 10.3923 /ajps.2004.709.713

Jaana, L., R. Rikala and P.J. Aphalo, 2002. Effect of CCC and daminozide on growth of silver birch container seedlings during three years after spraying. New For., 23: 71-80. DOI: 10.1023/A:1015645228689

Kramer, P.J. and T.T. Kozlowski, 1979. Physiology Woody Plants. Academic Press, New York.

Levy, Y., H. Bilorai and J. Schlhevet, 1978. Long term effect of different regimes on grapefruit tree development and yield. J. of Am. Soc. of Hort. Sci., 103: 680-683.

Malash, N.M.A.R. and T.J. Flowers, 1984. The effect of phenylmercuric acetate on salt tolerance in wheat. Plant and Soil, 81: 269-279. DOI: 10.1007/BF02197160

Mishra, D. and G.C. Pradhan, 1972. Effect of transpiration-reducing chemicals on growth, flowering and stomata opening of tomato plants. Plant Physiol., 50: 271-274.

Moriana, A., F.J. Villalobos and E. Fereres, 2002. Stomata and photosynthetic responses of olive (Olea europaea L.) leaves to water deficits. Plant Cell Environ., 25: 395-405. DOI: 10.1046/j.00168025.2001.00822

Prakash, M. and K. Ramachandran, 2000. Effects of chemical ameliorants on stomata frequency and water relations in Brinjal (Solanum melogena L.,) under moisture stress conditions. J. Agron. Crop Sci., 185: 237-239. DOI: 10.1111/j.1439037X.2000.00329
Rieger, M., 1995. Offsetting effects of reduced root hydraulic conductivity and osmotic adjustment following drought. Tree Physiol., 15: 379-385. DOI: 10.1093/treephys/15.6.379

Saei, A., Z. Zamani, A, Talaie and R. Fatahi, 2006. Influence of drought stress periods on olive (Olea europaea L. cv. Zard) leaves stomata. Inter. J. Agric. Biol., 4: 430-433. DOI: 15608530/2006/08-4-430-433

Skene, K.G.M. and M.G. Mullins, 1967. Effect of CCC on the growth of roots of Vitis vinifera L. Planta, 77: 157-163. DOI: 10.1007/BF00387452

Sofo, D., B. Dichio, C. Xiloyannis and A. Masia, 2004. Lipoxygenase activity and proline accumulation in leaves and roots of olive trees in response to drought stress. Physiol. Plantarum, 121: 58-65. DOI: 10.1111/j.0031-9317.2004.00294x

Torrecillas, A., C. Gullaume, J.J. Alarcon and M.C.R. Sanchez, 1995. Water relations of two tomato species under water stress and recovery. Plant Sci., 105: 169-176. DOI: 10.1016/01689452(94)04048-6

Xudan, X., 1986. The effect of foliar application of fulvic acid on water use, nutrient uptake and yield in wheat. Aus. J. Agric. Res., 37: 343-350. DOI: 10.1071/AR9860343 